\title{
射出発泡成形品の材料特性予測に対する 等価介在物法の妥当性検討
}

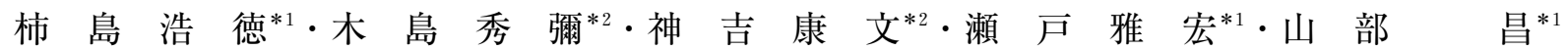 \\ Examination of the validity of an equivalent inclusion method for \\ material properties prediction of foamed articles by injection molding
}

\author{
Kakishima, Hironori*1/Kijima, Syuya*2/Kanki, Yasufumi*2/Seto, Masahiro*1/Yamabe, Masashi*1
}

In this study, in order to construct an analysis technique for the actual part that applies the injection foam molded plate, we examined a validity of the equivalent inclusion method for the prediction of macroscopic material properties of injection foam molded plate. As a first step of the construction of analysis techniques," Relationship of stress and strain" of the foam layer was predicted with the equivalent inclusion method, and Young's modulus was calculated. Comparing the results of analysis and tensile tests, although differences may occur in both results, there is good qualitative agreement. As a second step of the construction of analysis technique, bending stiffness was predicted in the structural analysis with FEM model consisting of skin layer and foam layer, and the results of analysis and three-point bending test were compared. For macroscopic Young's modulus of foam layer which is the input condition for the structural analysis, calculation by the rule of mixture and prediction by the equivalent inclusion method were attempted, and the significant difference of each approach was examined. As a result, the prediction results obtained by the equivalent inclusion method show a better agreement with the test results than the prediction results obtained by applying the rule of mixture. Therefore, it is presumed that there is significant difference in each approach. From the above results, for the prediction of macroscopic material properties of injection foam molded plate, it is presumed that the equivalent inclusion method has validity and high reliability.

Key words : Foamed articles by injection molding, Equivalent inclusion method, Material properties, Validity

\section{1. 緒言}

近年，樹脂の剛性や機械的強度を補うため，樹脂に比べ て高強度, 高剛性なガラス繊維等を組み合わせた繊維強化 樹脂等の複合材料に関する研究が盛んに行われている。一 方, 樹脂内部に多数の気泡を含んだ射出発泡成形品も繊維 強化樹脂のような複合材料の一種であり, 不均質材料と考

${ }^{* 1}$ 金沢工業大学

Kanazawa Institute of Technology 白山市八束穂 3-1（敄924-0838）

3-1, Yatsukaho, Hakusan, Ishikawa hiro-k@venus.kanazawa-it.ac.jp

*2(株)ユーイーエス・ソフトウェア・アジア

UES Software Inc.

横浜市中区不老町 1-6-9（采231-0032）

1-6-9, Furocho, Yokohama Naka-ku, Kanagawa 2013.12.27 受理
えることができる. 射出発泡成形品は, 無発泡成形品に比 べて軽量であり, 気泡による体積増加で材料の削減も期待 できる，さらに，射出発泡成形品は軽量，断熱性や緩衝性 等の優れた特性を活かして自動車部品等に多く実用化され ている.このように軽量化や断熱性等の特性を付与するこ とが可能である反面, 気泡が内部欠陥となり, 強度や剛性 が低下するといった課題も有している.

射出発泡成形品を応用した製品の設計・開発において, 必要不可欠となっているのが数值シミュレーションである. 製品が有する剛性や機械的強度等の巨視的な材料特性を事 前に予測することで, 試作回数を減らすことが可能なため, リードタイムの短縮やコスト削減が期待される. 射出発泡 成形品は，板厚方向に金型による冷却速度の分布が発生す るため, 流動・固化の過程でスキン層と発泡層が形成され, 板厚方向に多層構造を形成する. スキン層には気泡が存在 しないため，応力とひずみの関係等の材料特性を予測する 
ことは容易である。しかし，樹脂と気泡が混在する発泡層 は一種の複合材料と考えることができるため, 図 1 のよう なミクロモデルを作成して有限要素法により巨視的な材料 特性を予測する場合, 要素数や節点数は膨大なものとなり, モデルの作成やメッシュ生成に膨大な時間と手間を要する といった課題がある.

そこで, 本研究では等価介在物法と呼ばれる数值解析手 法に着目した。なお，等価介在物法の概要及び定式化は第 2 章に記述した。ここで, 等価介在物法に関する研究につ いて，山本 ${ }^{11}$ は，等価介在物法に基づいて木質細胞壁にお ける木材繊維の力学挙動をシミュレートすることで弾性構 成式を導出し, その有効性を実験的に検証している. 安田 $ら^{2)}$ は, 等価介在物法により破壊勒性の気孔率依存性及び 気孔形状依存性を定式化することで，七ラミックスの破壊 勒性に及ぼす組織の影響について検討している。しかし， 射出発泡成形品の巨視的な材料特性予測に対して，等価介 在物法が適用された研究報告は少ない.

本研究では, 射出発泡成形品を応用した実部品の解析技 術の構築を行うことを目的とし, 射出発泡成形品の巨視的 な材料特性予測に対する等価介在物法の妥当性を検討した。 まず発泡層の巨視的な材料特性を予測するため，等価介在 物法の定式化を行った. また成形品の発泡構造を観察し, 成形時に変化させた化学発泡剂の混合量と成形品の発泡構 造の関わりについて明らかにした．等価介在物法により発 泡層の巨視的な応力とひずみの関係を予測して弾性率を算 出するとともに，スキン層と発泡層から成る多層構造を模 した平板形状のモデルで構造解析を実施して成形品の曲げ 剛性を予測した.さらに, 射出発泡成形で得られた成形品 サンプルを使用して引張試験及び 3 点曲げ試験を実施し, 予測結果と試験結果を比較した. また, 複合材料の一種と 考えることのできる発泡層を図 1 のように忠実にモデル化 して巨視的な材料特性を得るのは膨大な時間や手間を要す るため, より端的に巨視的な材料特性を求める手法として,

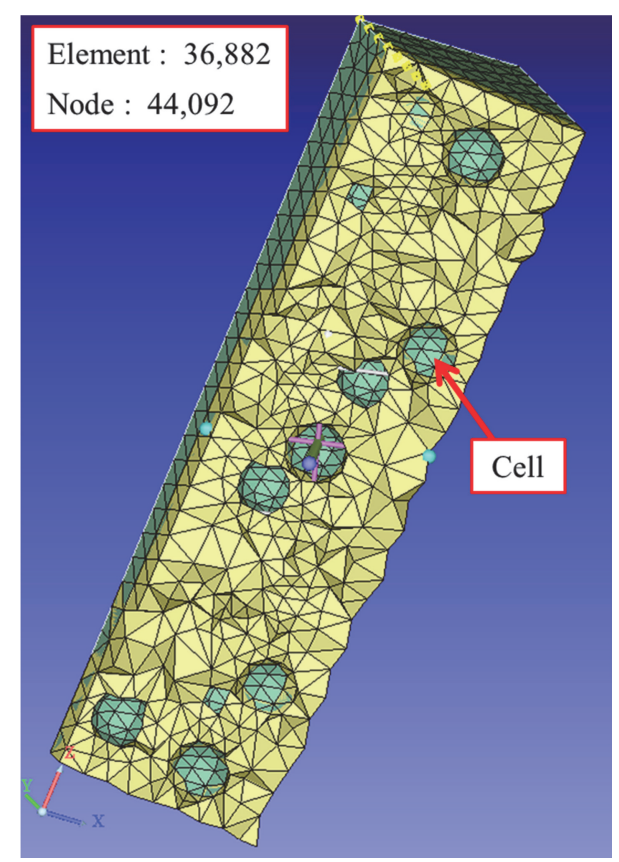

Fig. 1 Creation of micro-model and enormous meshing
古典的な基本法則である複合則がある ${ }^{3)}$. よって，本研究 では構造解析において成形品の曲げ剛性を予測するにあた り, 入力条件とした発泡層の巨視的な弾性率を, 発泡層を 均質材料と仮定して複合則による理論式で算出する場合と 等価介在物法を適用する場合の 2 通り実施した。構造解析 で予測した結果と 3 点曲げ試験の結果を比較することで, 射出発泡成形品の巨視的な材料特性予測に対する等価介在 物法の妥当性を検討した。

\section{2. 等価介在物法}

発泡層の巨視的な応力とひずみの関係を予測し, 弾性率 を算出する際に導入した等価介在物法について記述する.

等価介在物法は Eshelby ${ }^{4}$ によって証明され，この理論を もとに森・田中 ${ }^{5)}$ は, 複合材料の巨視的な材料特性（平均 弾性テンソル）を得る手法を導き，弾塑性領域まで拡張し た.ここでは, 発泡層の巨視的な応力とひずみの関係を導 くため, 森・田中のアプローチをもとに等価介在物法の定 式化を行った ${ }^{6)-9)}$.

不均質な材料特性を持つ介在物が多く含まれている複合 材料において，介在物による乱れを算定するため，図 2 の ように平均ひずみ? $\langle\varepsilon\rangle_{M}$ が発生する母材に介在物を 1 個 だけ加えてみると, 母材中, 介在物中の応力とひずみの関 係はそれぞれ式(1)，式(2)のように表現できる。なお， $C^{M}$ は母材, $C^{I}$ は介在物の弾性係数（弾性テンソル）であり, 変形状態にかかわらず一定である. また添え字はそれぞれ $M$ : 母材, $I$ : 介在物を意味する. また,〈〉は平均量で あり，式(2)における〈r $\rangle_{I}$ は乱されたひずみである. 実際 は, 不均質な材料特性を持つ介在物中の応力とひずみの関 係は式(2)で表現されるが，この不均質な材料特性を持つ介 在物を 1 個の等価介在物で置き換えると, 式(2)は式(3)のよ うに表現できる。

$$
\begin{gathered}
\langle\sigma\rangle_{M}=C^{M}\langle\varepsilon\rangle_{M} \\
\langle\sigma\rangle_{I}=C^{I}\langle\varepsilon\rangle_{I}=C^{I}\left\{\langle\varepsilon\rangle_{M}+\langle\gamma\rangle_{I}\right\} \\
\langle\sigma\rangle_{I}=C^{I}\left\{\langle\varepsilon\rangle_{M}+\langle\gamma\rangle_{I}\right\}=C^{M}\left\{\langle\varepsilon\rangle_{M}+\langle\gamma\rangle_{I}-\left\langle\varepsilon^{*}\right\rangle_{I}\right\}
\end{gathered}
$$

以上のような置き換えに基づいた解析手法が等価介在物 法であり，〈 $\left\langle\varepsilon^{*}\right\rangle_{I}$ は問題の等価性を保証するために導入さ れた固有ひずみである ${ }^{10)}$. 固有ひずみは周囲に拘束がない 場合, 内部に応力を伴わない変形と定義されている ${ }^{11)}$.こ のように等価介在物法は, 不均質な材料特性を持つ介在物

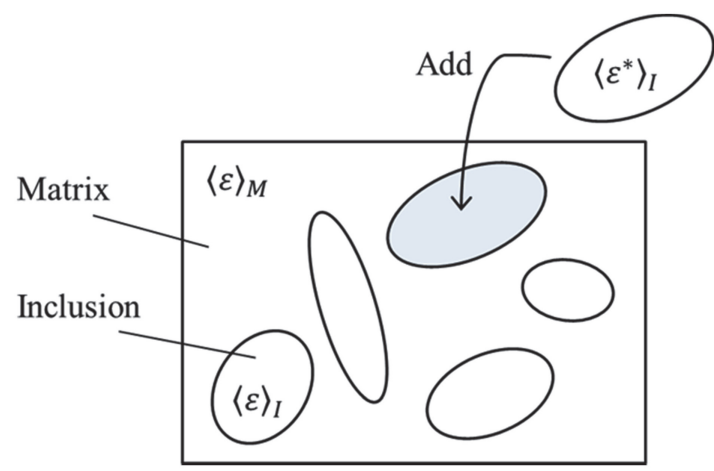

Fig. 2 Addition of heterogeneous inclusions 

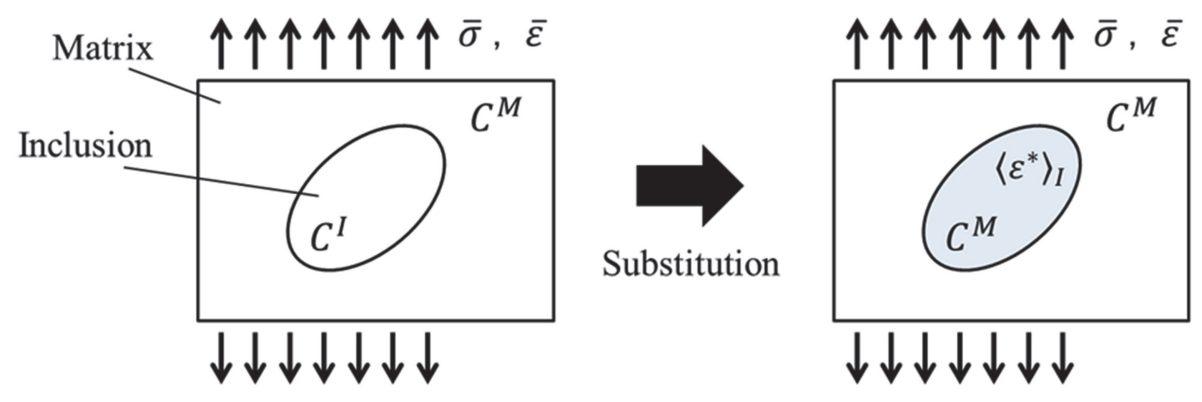

Fig. 3 Conceptual diagram of the Equivalent inclusion method

を母材と同じ弾性特性を持ち，内部に固有ひずみを有する 領域に置き換えて等価な応力場を考慮して適切な固有ひず みを求め, 巨視的な応力とひずみの関係を導く手法であ る ${ }^{12)}$. 図 3 に等価介在物法の概念図を示す.

ここで, Eshelby によって乱されたひずみ $\langle\gamma\rangle_{I}$ と固有ひ ずみ $\left\langle\varepsilon^{*}\right\rangle_{I}$ の関係が式(4)のように定義されている．Sは介 在物中の Eshelby テンソルであり, 介在物の形状と母材 のポアソン比に依存し，その大きさには依存しない。なお， 介在物の形状は楕円体または球体としている ${ }^{13)}$. また, 置 き換えにより導入された介在物の固有ひずみ $\left\langle\varepsilon^{*}\right\rangle_{I}$ は式(5) のようになり，介在物中の局所的な応力も式(6)で表される. さらに, 古典的な複合則 ${ }^{14)}$ 15) により, 複合材料の巨視的な 応力とひずみを体積平均で定義し, 式(5)と式(6)から固有ひ ずみ $\left\langle\varepsilon^{*}\right\rangle_{I}$ を消去すると, 式(7)のような関係が得られる。 $\bar{\sigma}$ と $\bar{\varepsilon}$ は巨視的な応力とひずみであり, $f$ は介在物の体積分 率である.よって, 巨視的な平均弾性テンソルを $\bar{C}$ とす れば, 複合材料 (発泡層) の巨視的な応力とひずみの関係 は，式(8)のように表現される。

$$
\begin{gathered}
\langle\gamma\rangle_{I}=S\left\langle\varepsilon^{*}\right\rangle_{I} \\
\left\langle\varepsilon^{*}\right\rangle_{I}=\left\{C^{M}-\left(C^{M}-C^{I}\right) S\right\}^{-1}\left(C^{M}-C^{I}\right)\left(C^{M}\right)^{-1}\langle\sigma\rangle_{M} \\
\langle\sigma\rangle_{I}=\langle\sigma\rangle_{M}+C^{M}(S-I)\left\langle\varepsilon^{*}\right\rangle_{I} \\
\bar{\varepsilon}=\left[C^{M}-\left(C^{M}-C^{I}\right)\{S-f(S-I)\}\right]^{-1} \\
\times\left[C^{M}-(1-f)\left(C^{M}-C^{I}\right) S\right]\left(C^{M}\right)^{-1} \bar{\sigma} \\
\bar{\sigma}=\bar{C} \bar{\varepsilon}
\end{gathered}
$$

\section{3. 射出発泡成形}

本研究では，等価介在物法による射出発泡成形品の巨視 的な材料特性予測に対する妥当性を検討するため, 引張試 験及び 3 点曲げ試験を実施し, 予測結果と試験結果との比 較を行った，各試験で使用する試験片を作成するため, 射 出発泡成形を実施した. 成形品の発泡構造との関わりにつ いて明らかにするため, 表 1 に示した成形条件のように化 学発泡剂の混合量を変化させた. なお, 比較対象のため, 化学発泡剂を混合しない条件 $(0 \mathrm{wt} \%)$ も併せて成形を実 施した。樹脂にはポリプロピレン (以下, PP), 化学発泡 剂にはポリスレン（永和化成工業）を使用して射出発泡成 形を実施した。図 4 に成形品の形状及び寸法を示す。また, コアバック成形法を採用し，成形品の標準板厚を $1.5 \mathrm{~mm}$,
Table 1 Molding conditions

\begin{tabular}{c|c}
\hline \hline Resin temperature $\left({ }^{\circ} \mathrm{C}\right)$ & 200 \\
\hline Mold temperature $\left({ }^{\circ} \mathrm{C}\right)$ & 30 \\
\hline Cooling time $(\mathrm{sec})$ & 50 \\
\hline Core back $(\mathrm{mm})$ & 1.5 \\
\hline Foaming agent $(\mathrm{wt} \%)$ & $0,1.0,1.5,2.0,2.5$ \\
\hline
\end{tabular}

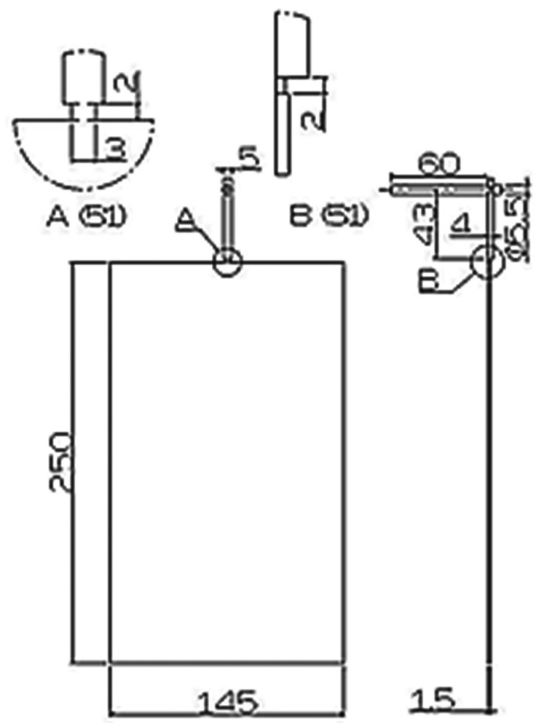

Fig. 4 Shape and dimensions of molded product (Unit : mm)

コアバック量（可動側の金型が開く量）を $1.5 \mathrm{~mm}$ とした. 本研究では, 圧力制御等の操作は行わずに, 上記のコアバッ ク量を成形機で設定し成形を実施した。なお，コアバック 成形法は, 図 5 のように溶融樹脂を金型内充填後, キャビ ティ容積を拡大し金型を開くことで生じる圧力変化により， 気泡の生成・成長を促進させる方法である。

\section{4. 発泡構造の観察}

\section{1 スキン層と発泡層の厚み}

成形において発泡剂の混合量を変化させることにより, 射出発泡成形品の発泡構造, 特に気泡径の分布が異なるこ とが推測される.さらに, 発泡構造が異なることによって 射出発泡成形品の材料特性は大きく変化すると考えられる。 本研究では, 発泡剂の混合量によって成形品の発泡構造が どのように, どの程度変化するのかを調べるため, 化学発 泡剂の混合量と成形品の発泡構造の関わりについて明らか にした。 まず，スキン層と発泡層の厚み，及び発泡構造を 


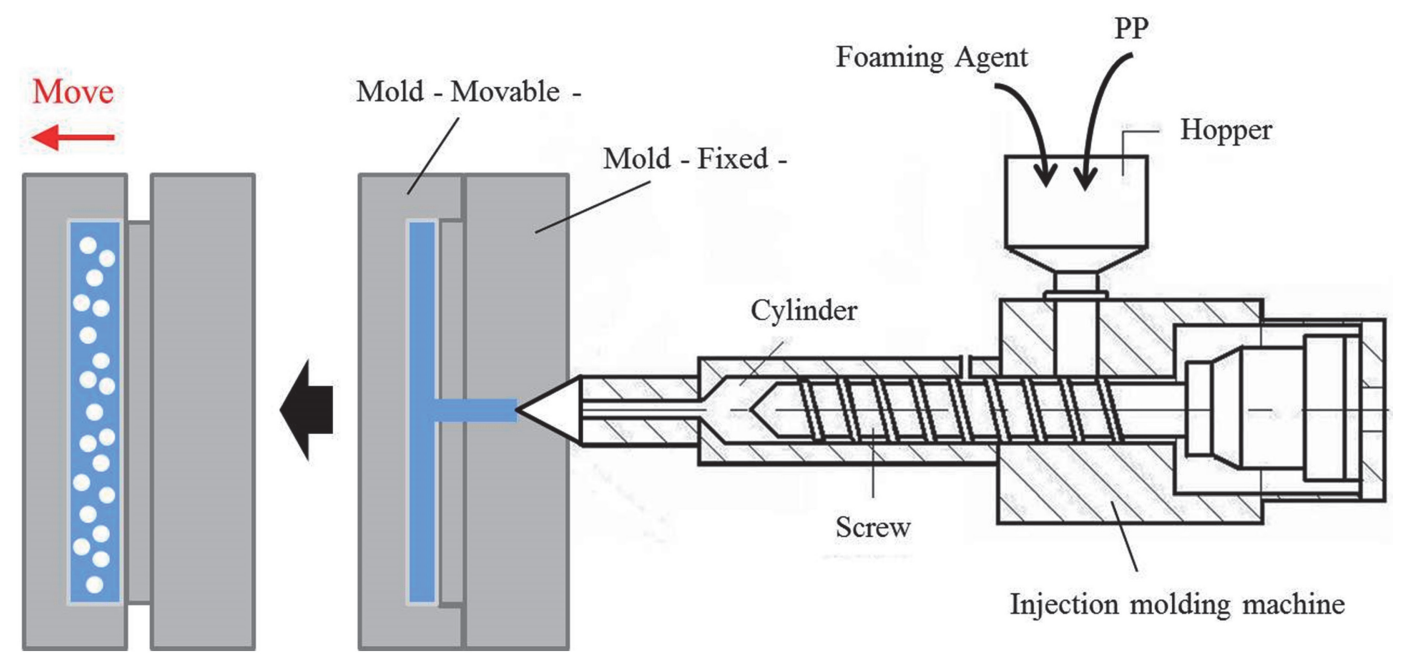

Fig. 5 Core-back molding

観察した．成形過程で金型による冷却速度の分布が板厚方 向に発生するため, 流動・固化の過程でスキン層と発泡層 が形成される．スキン層と発泡層の厚みを測定するために, 図 4 に示した成形品に打ける長手方向の中央で液体窒素を 使用して成形品を急速に冷凍し分割した。な押，成形品の 長手方向は，金型キャビティの長手方向に対応する．次に， その断面をデジタルマイクロスコープ（キーエンス，VHX -500) で撮影して画像を画像処理ソフト (ニコン, NIS-Elements D 3.1）に読み込み，画像に二值化処理を施すこと で測定した。本研究では, スキン層と発泡層について, 図 6 で示す成形品断面のように定義した。なお，図 6 に示し た成形品断面は, 発泡剂の混合量が $1.0 \mathrm{wt} \%$ の条件である.

図 7 に, 発泡剂の混合量による各層の厚みの推移を示す。 横軸は発泡剂の混合量 $[\mathrm{wt} \%]$, 縦軸は各層の厚み $[\mathrm{mm}]$ である. 図 7 より, 発泡剤の混合量が増加すると発泡層も 厚みが徐々に大きくなるが，スキン層の厚みに変化はみら れないことが分かる。これはコアバック成形法により可動 側の金型を開くことによって金型内の圧力変化が大きくな り，高い減圧効果が得られたためであると考えられる。さ らに発泡剤の混合量が多い条件では，コアバック成形法を 行う前の段階において加熱による分解で発生したガスが多 かったことも原因の一つであると推測される．また図７に 扔いて, 発泡層の厚み変化が顕著なのは発泡郕を混合しな い条件から混合量が $1.5 \mathrm{wt} \%$ 条件にかけてであり，よ り混合量を多くしても発泡層の厚み変化は小さいことが分 かった.

\section{2 発泡構造の観察}

発泡構造の観察は, 発泡剤の混合量によって気泡径の分 布がどの程度変化するのかを調べた．まず図 4 に示した成 形品に拀ける長手方向の中央で分割し，その断面をデジタ ルマイクロスコープで撮影する。次に撮影した成形品断面 の画像を画像処理ソフトに読み込み，画像に二值化処理を 施すことにより，気泡径を計測し相対度数を求めた.

図 8 に, 発泡剂の混合量が $1.0 \mathrm{wt} \%, 2.0 \mathrm{wt} \%$ の条件 に打ける成形品の断面画像及び気泡径の分布を併せて示す. なお，図 8 に示す気泡径の分布は横軸が気泡径 $[\mu \mathrm{m}]$ で あり, 縦軸が相対度数 [\%] である. 図 8 に示す成形品の

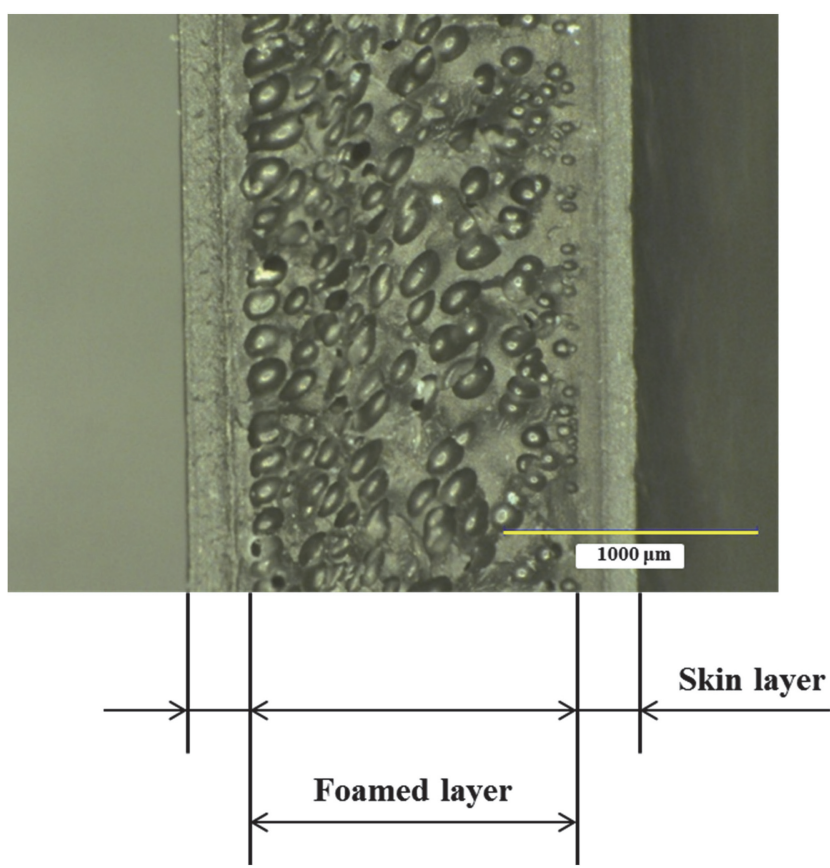

Fig. 6 Definition of skin layer and foam layer

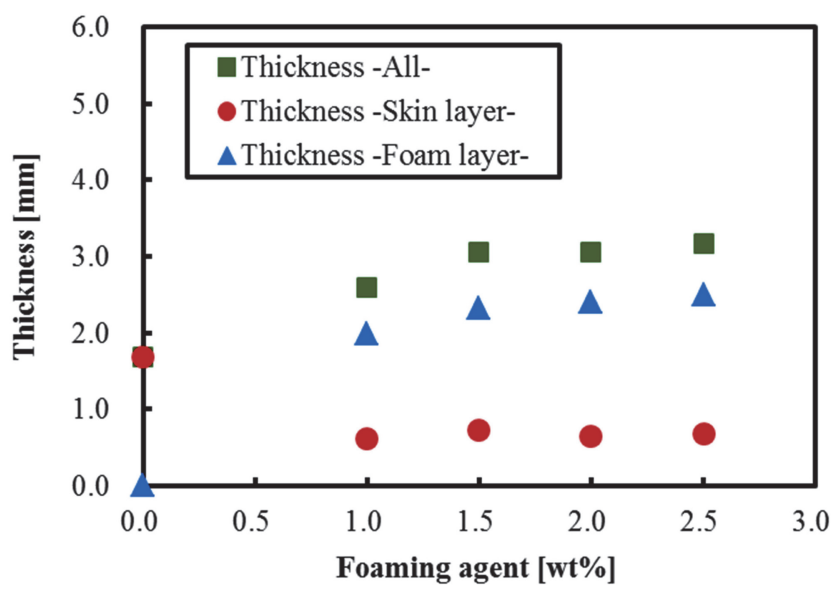

Fig. 7 Changes in the thickness of each layer 
断面画像から，発泡剂の混合量が $1.0 \mathrm{wt} \%$ 条件では, スキン層付近に径の小さい気泡が確認できるものの，板厚 方向において径の均一な気泡が分布していることが分かる. しかし, 発泡剤の混合量が $2.0 \mathrm{wt} \%$ 条件では, スキン 層付近に径の小さい気泡が多数存在し, 中心部に近づくほ ど気泡径が大きくなっており, 板厚方向に気泡径の分布が 生じている.これは図 8 に示した気泡径の分布において, 発泡剂の混合量が $1.0 \mathrm{wt} \%$ の条件では, 気泡径の平均值 に相対度数が集積するような正規分布に近い分布を示して いることからも確認できる。一方，発泡剤の混合量が 2.0 $\mathrm{wt} \%$ 条件では, $90 \mu \mathrm{m}$ 程度の比較的径の小さい気泡が 最も多く存在し, $330 \sim 390 \mu \mathrm{m}$ 程度の径の大きい気泡も存 在している. 以上の結果から, 発泡剂の混合量が少ない条 件では板厚方向に気泡径の大小にバラつきが小さく均一な 気泡径の分布を示し, 一方で混合量が多い条件では気泡径 のバラつきが大きいことが明らかとなった.

\section{5，等価介在物法の妥当性検討}

\section{1 発泡層の弾性率予測}

本研究では, 射出発泡成形品を応用した実部品の解析技 術の構築を行うことを目的とし，その巨視的な材料特性を 予測する際に導入した等価介在物法の妥当性を検討した. ここでは解析技術の構築の第一段階として, 等価介在物法 により発泡層の巨視的な応力とひずみの関係を予測し, 弾 性率を算出した。さらに等価介在物法の妥当性を検討する ため, 引張試験を実施し，予測結果と試験結果を比較した.

図 9 に, 本研究における射出発泡成形品の材料特性予測 の流れを示す．第 2 章で述べた等価介在物法の定式化をも とに，材料特性值計算ソフトウェア DIGIMAT-MF（e-
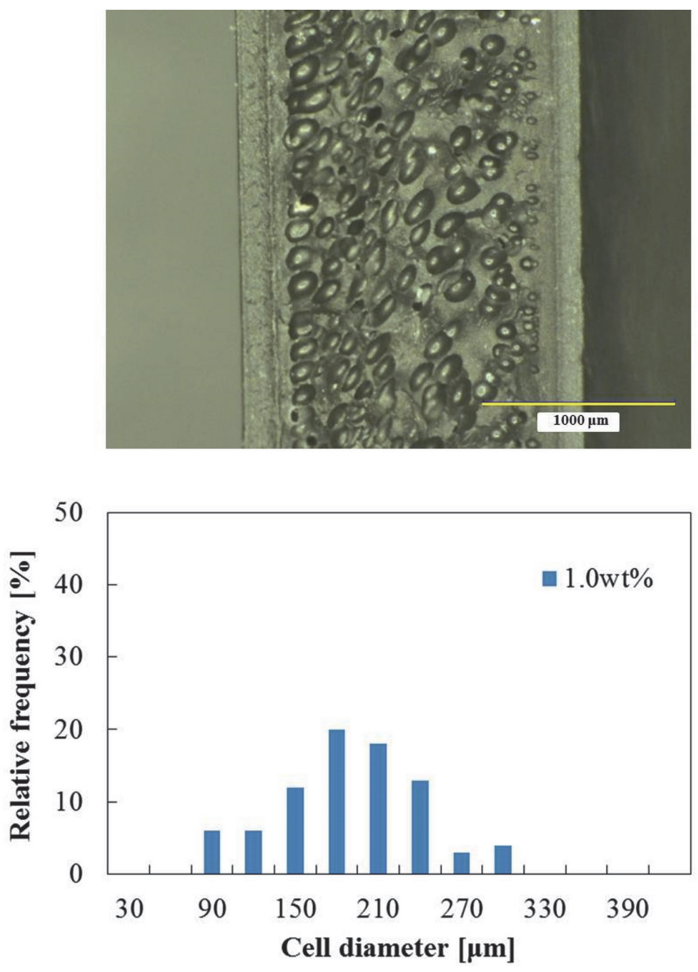

(a ) $1.0 \mathrm{w} \mathrm{t} \%$
Xstream engineering）を使用し，発泡層の巨視的な応力 とひずみの関係を予測して弾性率を算出した。材料特性值 計算ソフトゥェア DIGIMAT-MF は等価介在物法をべー スとし, 樹脂と介在物の材料特性值や介在物の体積分率を 入力することで, 複合材料の非線形な応力とひずみの関係 を巨視的に予測可能なソフトウェアである. 平板形状の発 泡層を模したモデルが一軸方向に引張変形を受けている場 合を想定し，発泡層の巨視的な応力とひずみの関係を予測 した.PPの材料特性值として密度, 弾性率及びポアソン 比を採用し，ポアソン比は 0.4 とした。 また従来，複合材 料として代表的な繊維強化樹脂の巨視的な材料特性を等価 介在物法により予測するにあたって, 䋊維フィラー等の介 在物の材料特性值や体積分率, 形状, 配向分布が入力条件 として用いられていた ${ }^{16)}$. しかし，本研究では射出発泡成 形品を対象としており，樹脂と気泡が混在する発泡層は一 種の複合材料として考えられる.そのため介在物を気泡と し，その材料特性值は持たず，配向分布も生じていないも のとした.さらに，気泡の大きさは考慮せず，その形状は アスペクト比を持たない完全な球体と仮定した．気泡の体 積分率は, 成形時に発泡剂の混合量を変化させた各条件に より得られた成形品の発泡構造から求めた（表 2).

引張試験は，図 4 で示した成形品の中央部から $100 \mathrm{~mm}$ $\times 20 \mathrm{~mm}$ のものを切り出し，スキン層をサンドペーパー で除去して発泡層のみの試験片で実施した。試験は，オー トグラフ $\mathrm{AG}^{-1}$ （島津製作所）を使用して，一般的な引張 試験に使用されるつかみ具（チャック）で試験片を固定し， 試験速度 $5 \mathrm{~mm} / \mathrm{min}$ で実施した. なお, 発泡剤を混合し ていない条件についても, 発泡層は形成されていないもの とし，同様に弾性率を測定した。図 10 に，等価介在物法
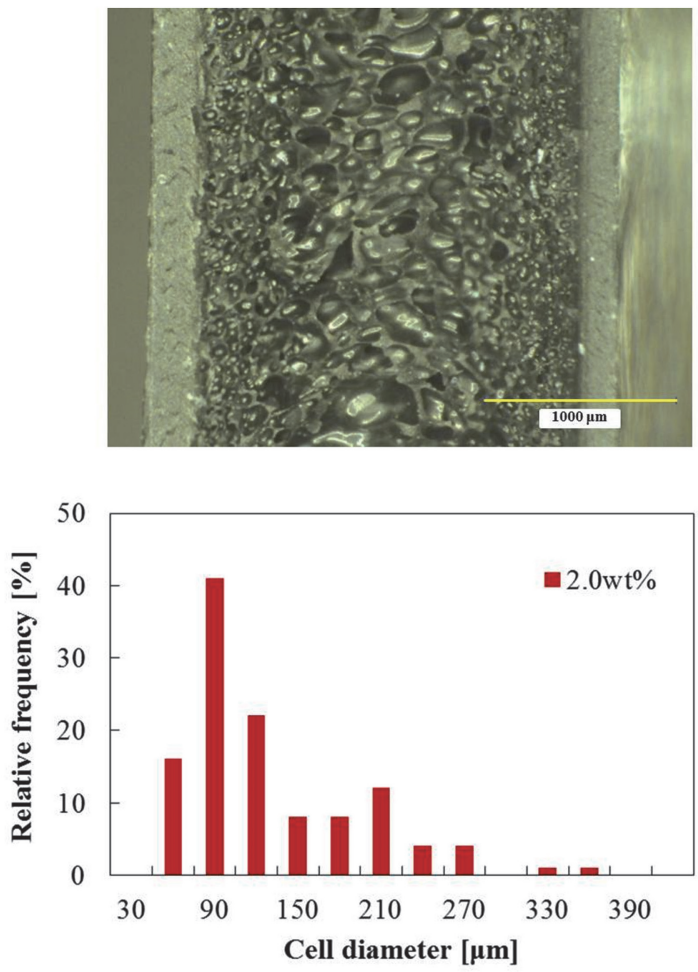

( b ) $2.0 \mathrm{wt} \%$

Fig. 8 Distribution of cell diameter 


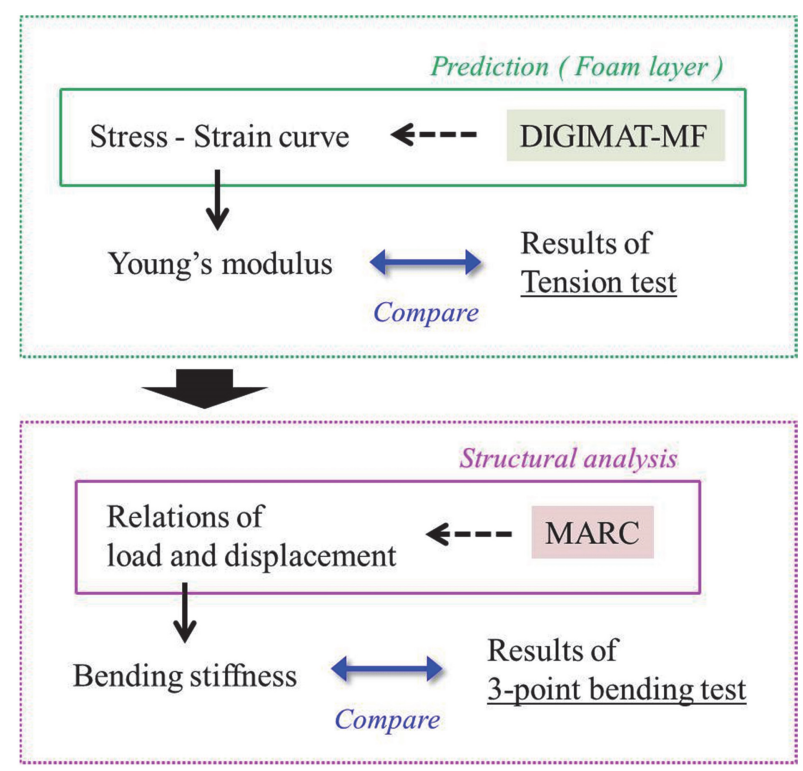

Fig. 9 Flow of analysis

Table 2 Volume fraction of cell

\begin{tabular}{c|c|c|c|c|c}
\hline \hline Foaming agent(wt\%) & 0 & 1.0 & 1.5 & 2.0 & 2.5 \\
\hline Volume fraction(\%) & - & 44.4 & 54.6 & 52.1 & 63.8 \\
\hline
\end{tabular}

の導入により予測した発泡層の弾性率，及び引張試験で測 定した弾性率を示す。なお，図 10 において横軸は発泡剂 の混合量 $[\mathrm{wt} \%]$, 縦軸が弾性率 $[\mathrm{MPa}]$ である。図 10 から予測結果と試験結果を比較すると, 発泡剤の混合量に ついていずれの条件でも両者の結果に差は生じるものの, 定性的には良好な一致を示すことが分かった。

\section{2 構造解析による成形品の曲げ剛性予測}

本研究では射出発泡成形品を応用した実部品の解析技術 を構築することを目的とし，その第一段階として，5.1節 では発泡層の巨視的な材料特性予測に対する等価介在物法 の妥当性を検討した。ここでは第二段階として，スキン層 と発泡層から成る多層構造を模した平板形状のモデルで構 造解析を実施し，射出発泡成形品の曲け剛性を予測した。 自動車部品等の実部品は使用環境によって異なるが，外力 によって引張や曲げ, ねじり, 座屈の変形が生じる.よっ て実用化されるためには, 外力に対する変形の予測精度が 重要となる。 そこで, 本研究では, 曲げ剛性に着目して議

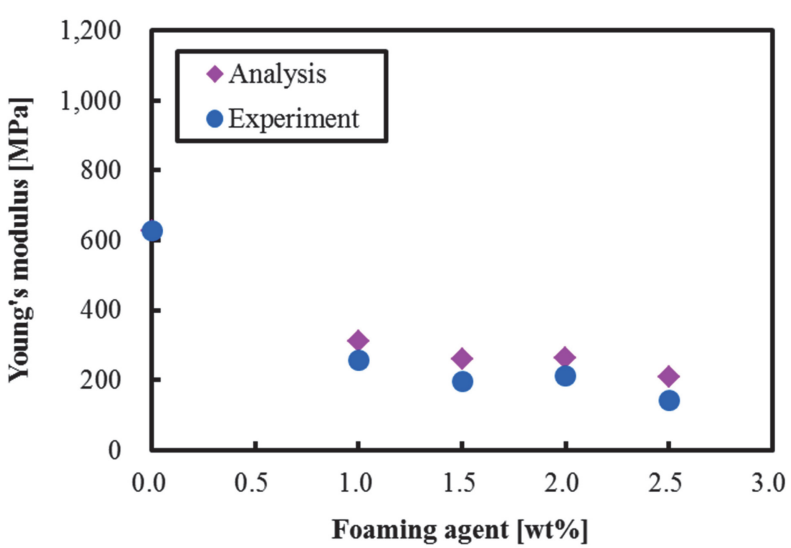

Fig. 10 Prediction results and the results of tension test

(Young's modulus of foam layer)

Table 3 Young's modulus of foam layer (Rule of mixture)

\begin{tabular}{c|c|c|c|c}
\hline \hline Foaming agent (wt\%) & 1.0 & 1.5 & 2.0 & 2.5 \\
\hline Young's modulus of PP(MPa) & \multicolumn{4}{|c}{625.8} \\
\hline Volume fraction of cell $(\%)$ & 44.4 & 54.6 & 52.1 & 63.8 \\
\hline Young's modulus $(\mathrm{MPa})$ & 347.9 & 284.1 & 299.8 & 226.5 \\
\hline
\end{tabular}

論を進める．構造解析の妥当性を検討するため, 3 点曲げ 試験を実施し，予測結果と試験結果を比較した。ささら， 複合材料の一種と考えることができる発泡層を均質材料と 考え，式(9)に示す古典的な複合則で算出した発泡層の弾性 率（表 3）をもとに, 構造解析で成形品の曲げ剛性を予測 し，上記の結果と比較した。なお，式(9)において，気泡の 弾性率 $E_{c}$ は考慮せず, $E_{\text {foam }}$ : 発泡層の弾性率, $V_{c}$ : 気泡 の体積分率, $E_{m}: \mathrm{PP}$ の弾性率である.

$$
E_{\text {foam }}=E_{c} V_{c}+E_{m}\left(1-V_{c}\right)
$$

構造解析は，汎用構造解析ソルバーMARC（MSC Software）を使用し，図 11 に示すようなスキン層と発泡層か ら成る多層構造を模した平板形状の 2 次元 FEM モデルで 実施した。なお，解析タイプは線形とし，入力条件には各 層の材料特性である応力とひずみの関倸（非線形）を採用 した，スキン層の材料特性には，引張試験で測定した発泡 凰を混合していない条件のものを使用した．発泡層の材料

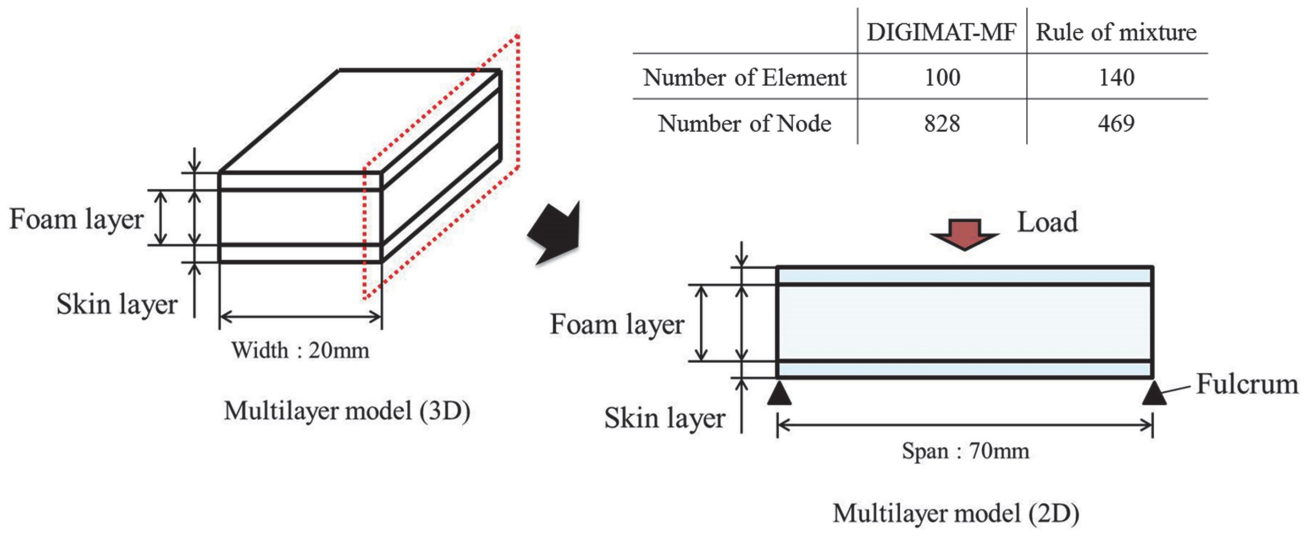

Fig. 11 Multi-layer model for the structural analysis (FEM model 3-point bending test) 
特性には，5.1節において等価介在物法の導入により予測 したものを使用した。曲げ剛性は, 構造解析で予測した荷 重と変位の関係から弾性率を算出し, 式(10)に示す一般的な 平板の曲げ剛性を求める式によって算出した ${ }^{17)}$. 式(10)にお いて, $D$ : 曲げ剛性, $E$ : ヤング率, $h$ : 試験片の板厚, $\nu$ : ポアソン比である. なお, ポアソン比は各条件とも 0.4 と した.

$$
D=\frac{E \cdot h^{3}}{12\left(1-\nu^{2}\right)}
$$

さらに発泡層を均質材料と仮定し, 複合則による理論式 から算出した巨視的な弾性率を入力条件として構造解析を 実施した。ここでは, 等価介在物法の導入により発泡層の 材料特性を予測した場合と同様の方法で解析を実施した. 曲げ剛性は, 構造解析で得られた各条件の最大たわみから 式(11)で算出した ${ }^{18)}$. 式(11)において, 弾性率と断面二次モー メントの積 $E I$ を曲げ剛性, $P$ : 荷重, $l$ : 支点間距離 $(70$ $\mathrm{mm}), w$ : 最大たわみとした.

$$
E I=\frac{P l^{3}}{48 w}
$$

3 点曲げ試験は, 図 4 で示した成形品の中央部から 80 $\mathrm{mm} \times 20 \mathrm{~mm}$ の試験片を作成し, 小型万能試験機 EZ Test （島津製作所）を使用して支点間距離 $70 \mathrm{~mm}$, 試験速度 5 $\mathrm{mm} / \mathrm{min}$ で実施した. 成形品の曲げ剛性は, 3 点曲げ試験 で得られた荷重と変位の関係から弾性率を求め, 構造解析 と同様に式（10）で算出した.

成形品の曲げ剛性について, 図 12 に予測結果と試験結 果を示す。図 12 において，横軸は発泡剂の混合量 [wt\%], 縦軸は曲げ剛性 $[\mathrm{N} \cdot \mathrm{mm}]$ である. 図 12 から, 等価介在 物法で予測した発泡層の巨視的な弾性率を入力条件とした 構造解析で得られた曲げ剛性の予測結果, 及び 3 点曲げ試 験の結果を比較すると, 発泡剂の混合量が $1.5 \mathrm{wt} \%$ 以下 の条件では, 予測結果と試験結果は定量的に良好な一致を 示すことが分かった。一方，発泡剤の混合量が $2.0 \mathrm{wt} \%$ 以上の条件において, 予測結果と試験結果に若干の差が生 じているのは, 発泡剂の混合量が少ない条件と比べて成形 品の発泡構造が異なるためであると考えられる. 図 8 から,

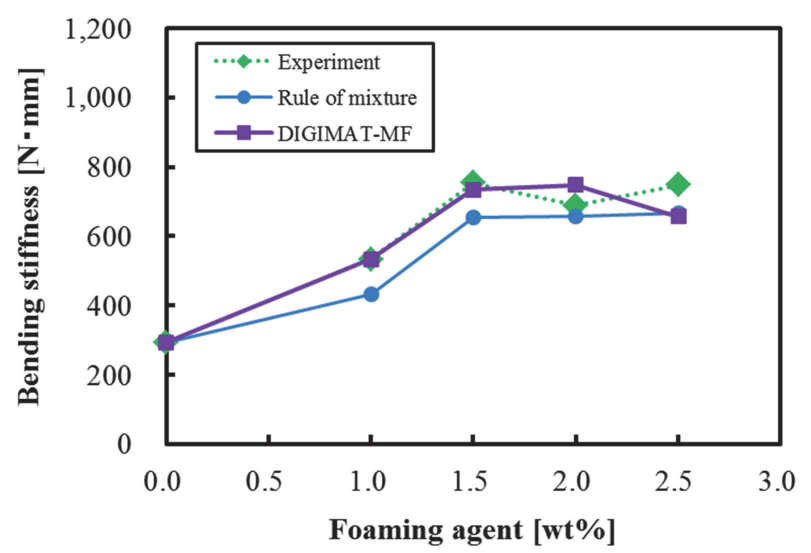

Fig. 12 Prediction results and results of 3-point bending test

(Bending stiffness of molded product)
発泡剂の混合量が少ない条件では，板厚方向に気泡径の大 小にバラつきが小さく均一な発泡状態であるのに対し, 混 合量が多い条件では気泡径のバラつきが大きい. 等価介在 物法により発泡層の応力とひずみの関係を巨視的に予測す る場合, 板厚方向における気泡径のバラつきを現段階では 考慮できない. そこで, まず板厚方向における気泡径のバ ラつきを考慮して, 成形品の発泡構造を図 1 で示したミク ロモデルで再現し, 有限要素法により発泡層の巨視的な材 料特性を予測する。これを入力条件として構造解析を行う ことで, 発泡剂の混合量が多い条件でも, 成形品の曲げ剛 性の予測結果と試験結果は定量的に良好な一致を示すと考 えられる。しかし, 図 12 から, 発泡剤の混合量が多い条 件において，予測結果と試験結果に若干の差が生じている ものの，定性的には良好な一致を示していると推測される. 一方，発泡層を均質材料と仮定して複合則を適用した場合， 発泡剂の混合量が $2.0 \mathrm{wt} \%$ 以上の条件において, 等価介 在物法を適用した場合に比べ, 予測結果は試験結果に近い 傾向を示す。しかし，複合則を適用した場合，発泡剂の混 合量が少ない条件では, 等価介在物法を適用した場合に比 べて, 予測結果と試験結果に大きな差が生じていることが 分かった。

以上より，発泡剤の混合量が少ない条件において，等価 介在物法を適用した場合, 発泡層を均質材料と仮定して複 合則を適用した場合に比べ，曲げ剛性の予測結果と試験結 果は定量的に良好な一致を示す。また，発泡剂の混合量が 比較的多い条件において, 複合則を適用した場合, 等価介 在物法を適用した場合に比べ, 予測結果は試験結果に近い 傾向を示す.しかし，両手法の差はごく僅かであり，等価 介在物法を適用した場合, 発泡剂の混合量が比較的多い条 件においても, 予測結果と試験結果は定性的に良好な一致 を示していると考えられる。このことから，等価介在物法 を適用した場合，発泡剂の混合量によらず，予測結果は試 験結果に近い傾向を示すことが明らかとなった。したがっ て, 射出発泡成形品の巨視的な材料特性予測に対して，等 価介在物法は高い信頼性と妥当性を備えていると推測され る.しかし, 射出発泡成形品を応用した自動車部品等の実 部品は, 本研究で想定した平板形状だけでなく, 用途ある いは要求される性能によって異なるが, リブやボス形状の ような複雑な形状のものが多く採用されている. 故に, 射 出発泡成形品を応用した実部品の解析技術を構築するにあ たり, 次の段階として, 部品形状を単純な平板形状から実 部品により近い複雑な形状に拡張する必要があると考えら れる。

\section{6. 結言}

本研究では，射出発泡成形品を応用した実部品の解析技 術の構築を行うことを目的とし, 射出発泡成形品の巨視的 な材料特性予測に対する等価介在物法の妥当性を検討した. 解析技術の構築の第一段階として, 等価介在物法により 発泡層の巨視的な応力とひずみの関係を予測し, 弾性率を 算出した.さらに等価介在物法の妥当性を検討するため, 引張試験を実施し, 予測結果と試験結果を比較した。これ により, 発泡層の弾性率について両者の結果に差は生じる ものの，定性的には良好な一致を示すことが分かった。ま 
た第二段階として，スキン層と発泡層から成る多層構造を 模した平板形状のモデルで構造解析を実施し, 成形品の曲 げ剛性を予測した.さらに 3 点曲げ試験を実施し，構造解 析の妥当性を検討した。これにより，発泡剂の混合量が少 ない条件では，予測結果と試験結果は定量的に一致し，混 合量が多い条件でも若干の差が生じているものの, 定性的 に良好な一致を示していると考えられる．また，等価介在 物法を適用した構造解析で予測した成形品の曲げ剛性は, 発泡剂の混合量によらず，試験結果に近い傾向を示すこと が明らかとなった。

以上より，等価介在物法は射出発泡成形品の巨視的な材 料特性予測に対して, 高い信頼性と妥当性を備えていると 推測される.今後の課題として, 想定する部品形状を実部 品により近いものに拡張する必要があると考えられる.形 状がより実部品に近い射出発泡成形品の材料特性予測に対 して，等価介在物法が高い信頼性と妥当性を備えているこ とが明らかとなれば，さらなるリードタイムや生産コスト の短縮・削減が可能であり, 実部品の設計・開発分野にお いて大いに活用できると期待される.

\section{参 考 文 献}

1 ）山本浩之：日本機械学会〔No.06-9〕第 19 回計算力 学講演会講演論文集，99(2006)

2 ）安田公一, 松尾陽太郎, 木村脩七, 森勉 : 日本セラミッ クス協会学術論文誌，99，737(1991)

3 ) 宮入裕夫 : 機能材料 - 高機能化と複合設計 - , 技報堂 出版, 34 (2003)

4 ) Eshelby, J. D. : The determination of the elastic field of an ellipsoidal inclusion, and related problems, Proc.
Roy. Soc. London, A 241, 376 (1957)

5 ) Mori, T. and Tanaka, K. : Average stress in matrix and average elastic energy of materials with misfitting inclusions, Acta metallurgica, 21, 571 (1973)

6 ）黑木誠一郎, 中沢正利, 岩熊哲夫 : 土木学会応用力学 論文集，8，377(2005)

7 ) 樋口耕平, 岩熊哲夫：土木学会応用力学論文集, 8, 367 (2005)

8 ）小山茂, 岩熊哲夫, 堀宗朗 : 土木学会構造工学論文集, 42 A，291 (1996)

9 ) 王峰, 岩熊哲夫, 小山茂：土木学会構造工学論文集, 51 A, 1387 (2005)

10）山口栄輝, 堀宗朗, 久保喜延, 安部剛史 : 土木学会論 文集，No.556/I-38，85(1997)

11）小川雅：日本機械学会論文集 (A 編)， 79 (804)，202 (2013)

12）高野直樹, 浅井光輝, 上辻靖智 : マイクロメカニカル シミュレーション，コロナ社，31(2008)

13）坂田誠一郎，芦田文博，小嶋友之：日本機械学会論文 集 (A 編)，75(756)，79(2009)

14）尾中晋，安藤嘉門：日本金属学会誌，63(10), 1283 (1999)

15）日本材料学会：機械材料学, 日本材料学会, 318(1991)

16）橋本雅弘, 岡部朋永, 西川雅章: 日本複合材料学会 誌, $37(4)$, $138(2011)$

17）材料力学教育研究会編 : 新形式材料力学の学び方 - 解 き方，共立出版，182(1994)

18）木田外明, 河端裕, 新保實 : わかりやすい材料力学の 基礎，共立出版，54（2003） 